Case Report

\title{
A REPORT OF A HEPATOZOON CANIS INFECTION IN A DOG WITH TRANSMISSIBLE VENEREAL TUMOUR
}

\author{
Namakkal Rajamanickam Senthil, Subramanian Subapriya, Subbaiah Vairamuthu \\ Centralised Clinical Laboratory \\ Madras Veterinary College, Chennai - 600007, Tamil Nadu, India \\ Received 17 March 2015; Received in revised form 3 June 2015; Accepted 10 June 2015
}

\begin{abstract}
In the present study, a case of a Hepatozoan canis infection in a dog with a sexually transmissible venereal tumour is reported. Haematological examination revealed marked decrease in haemoglobin, PCV and RBC counts and the blood smear revealed rouleaux formation of RBC, hypochromasia, leptocytes and neutrophilia. Neutrophils were parasitized with both non-nucleated and stained nucleated forms of $H$. canis. Serum biochemistry results showed elevated levels of alkaline phosphatise, whereas blood urea nitrogen, creatinine, total protein, albumin and globulin were in the normal range.
\end{abstract}

Key words: canine, transmissible venereal tumour, Hepatozoon canis

\section{INTRODUCTION}

Transmissible venereal tumour (TVT) is a reticuloendothelial tumour in dogs that mainly affects the external genitalia and occasionally the internal genitalia (1). It is sexually transmitted by coitus and other contacts and is also known as infectious sarcoma, venereal granuloma, transmissible lymphosarcoma or sticker tumour. TVT affects the mucosa of the external genitalia and less often, the internal genitalia (2). According to Cohen (3), the exfoliation and transplantation of neoplastic cells during physical contact provide the main mode of transmission onto genital mucosa, and also onto nasal or oral mucosa, during mating or licking of affected genitalia, respectively. Canine hepatozoonosis is caused by Hepatozoon canis and transmitted by ingestion of an Ixodid tick, Rhipicephalus sanguineus containing mature oocysts (4). Hepatozoon spp. are protozoa of the

Corresponding author: Assist. Prof. N.R.Senthil, M.V.Sc.

E-mail address: drnrsenthil@gmail.com

Present address: Centralised Clinical Laboratory

Madras Veterinary College, Chennai- 600007, Tamil Nadu, India

Phone: ++91-9500189671

Copyright: (C) 2015 Senthil N.R. This is an open-access article published under the terms of the Creative Commons Attribution License which permits unrestricted use, distribution, and reproduction in any medium, provided the original author and source are credited.

Competing Interests: The authors have declared that no competing

interests exist.

Available Online First:15 June 2015

http://dx.doi.org/10.14432/j.macvetrev.2015.06.046 phylum Apicomplexa, some of which parasitize the white blood cells of dogs. At present, two species of Hepatozoon have been identified in dogs: H. canis which is transmitted by Rhipicephalus sanguineus, and $H$. americanum which is transmitted by Amblyoma maculatum. Between H. canis and H. americanum there are differences in morphology, pathogenicity, tissue tropism and clinical signs. In particular, H. americanum is much more pathogenic and can be lethal. The dog is infected when it ingests a tick containing sporulated oocysts. The sporozoites are released in the dog's digestive tract, penetrate the intestinal wall and are carried by the blood or lymph to the liver, lymph nodes, kidneys, bone marrow and muscle where schizogony occurs. Numerous merozoites develop, some of them enter neutrophils and monocytes and transform into gametocytes. All Hepatozoon spp. share a basic life cycle that includes sexual development and sporogony in a hematophagous invertebrate definitive host, and merogony followed by gamontogony in a vertebrate intermediate host. Definitive hosts for Hepatozoon spp. are blood-sucking invertebrates, including ticks, mites, sand flies, tsetse flies, mosquitoes, fleas, lice, reduviid bugs, and leeches (5). To the author's knowledge this is the first report of $H$. canis infection associated with a TVT case in India and hence the case is recorded and discussed. 


\section{CASE REPORT}

A 14-year-old Spitz female dog with a growth in the caudal vagina protruding from the vulva was presented at the small animal clinics surgery biochemistry and blood smear for Leishman-Giemsa staining were carried out at the centralized clinical laboratory. The whole blood was analysed by auto haematology analyser (BC-2800 Vet) and serum biochemistry in A15 auto analyser. FNAC touch

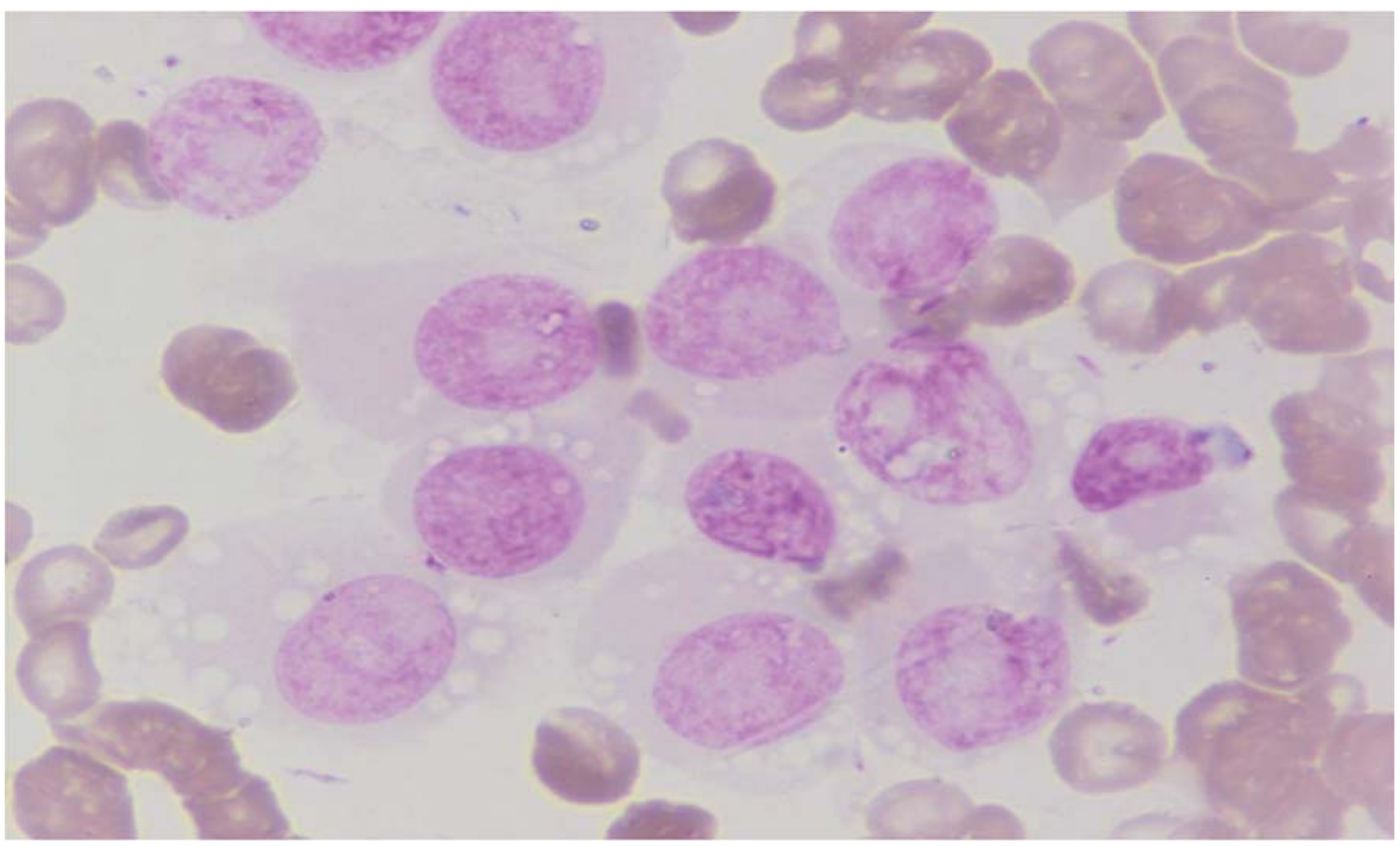

Figure 1. Cytological smear from a vulval mass showing discrete round cells with eccentric round nuclei, uniform granular chromatin pattern and clear, cytoplasmic vacuoles

(outpatient unit) of the Teaching Veterinary Hospital at the Madras Veterinary College. On examination the mass was suggestive of TVT by fine needle aspiration cytology (FNAC) sample submitted for cytological examination. Blood samples were collected for haematology in EDTA vials; serum impression smear was taken from the mass, then stained with Leishman-Giemsa stain for cytological examination.

Cytological smear from the protruding vulval mass showed discrete round cells having eccentric round nuclei with uniform granular chromatin

Table 1. Haemological and sero-biochemical values of H.canis infected TVT dog

\begin{tabular}{llllll}
\hline Haematology & Value & Reference values & $\begin{array}{l}\text { Serum } \\
\text { Biochemistry } \\
\text { parameters }\end{array}$ & Value & Reference Values \\
\hline Haemoglobin & $3.8 \mathrm{mg} / \mathrm{dL}$ & $12-18 \mathrm{mg} / \mathrm{L}$ & BUN & $18.84 \mathrm{mg} / \mathrm{dL}$ & $10-28 \mathrm{mg} / \mathrm{dL}$ \\
PCV & $15.7 \%$ & $37-55 \%$ & Creatinine & $1.08 \mathrm{mg} / \mathrm{dL}$ & $0.5-1.5 \mathrm{mg} / \mathrm{dL}$ \\
RBC & $2.72 \mathrm{~m} / \mathrm{cubic} \mathrm{mm}$ & $5.5-8.5 \mathrm{~m} / \mathrm{cmm}$ & Total protein & $6.4 \mathrm{~g} / \mathrm{dL}$ & $5.4-7.1 \mathrm{~g} / \mathrm{dL}$ \\
WBC & $30,700 / \mathrm{cubic} \mathrm{mm}$ & $6000-17000 / \mathrm{cmm}$ & Albumin & $1.8 \mathrm{~g} / \mathrm{dL}$ & $2.3-3.8 \mathrm{~g} / \mathrm{dL}$ \\
Platelets & $5,06,000 / \mathrm{cmm}$ & $200000-500000 / \mathrm{cmm}$ & Globulin & $4.6 \mathrm{~g} / \mathrm{dL}$ & $2.3-5.2 \mathrm{~g} / \mathrm{dL}$ \\
Neutrophils & $90 \%$ & $60-70 \%$ & AST & $50.0 \mathrm{IU} / \mathrm{L}$ & $23-66 \mathrm{IU} / \mathrm{L}$ \\
Lymphocytes & $8 \%$ & $20-30 \%$ & ALP & $476.0 \mathrm{IU} / \mathrm{L}$ & $20-156 \mathrm{IU} / \mathrm{L}$ \\
Monocytes & $2 \%$ & $0-5 \%$ & Total bilirubin & $0.40 \mathrm{mg} / \mathrm{dL}$ & $0.15-.0 .50 \mathrm{mg} / \mathrm{dL}$ \\
& Rouleaux formation of RBC, Hypochromasia, & Direct bilirubin & $0.21 \mathrm{mg} / \mathrm{dL}$ & $0.06-0.12 \mathrm{mg} / \mathrm{dL}$ \\
Blood picture & Leptocytes, Neutrophilia & Calcium & $8.81 \mathrm{mg} / \mathrm{dL}$ & $9-11.3 \mathrm{mg} / \mathrm{dL}$ \\
\hline
\end{tabular}


Hepatozoon canis infection in a dog with TVT- Case report

pattern and a single round prominent nucleolus, as shown in Figure 1. The microscopic features of the cytological smear were thus suggestive of TVT. Neoplastic cells ranged from 12-24 $\mu \mathrm{m}$ in diameter and they had moderate amounts of granular and moderately blue staining cytoplasm. Cells revealed clear, distinct, punched out cytoplasmic vacuoles. The vacuoles were similar in size and arranged in linear array along the inner surface of the cell membrane. In addition to the neoplastic cells, normal appearing neutrophils and lymphocytes were seen.

Haematological and serum biochemistry results are showed in Table 1. Haematological examination revealed marked decrease in haemoglobin $(3.8 \mathrm{~g} / \mathrm{dl})$, packed cell volume (PCV) (15.7\%) and RBC count (2.7 million cells $/ \mathrm{mcL})$, while the blood smear revealed rouleaux formation of $\mathrm{RBC}$, hypochromasia, leptocytes and neutrophilia. Neutrophils were parasitized with both nonnucleated and stained nucleated forms of $H$. canis, as shown in Figure 2.

Serum biochemistry results showed elevated levels of Alkaline phosphatase (ALP) (476.0 IU/L) whereas BUN, creatinine, total protein, albumin and globulin were in the normal range, as shown in Table 1. damaged skin and mucosa (6). Stockmann et al. (7) observed tumour formation in the posterior region of the vagina and vestibule-vaginal junction, which was prolapsed out of the vulva of bitches. TVT usually occur in bitches within the age group of 2-8 years (8). In this study an increased level of ALP was observed. According to Kerr (9), increased activities of serum AST, ALT and ALP may be due to liver damage, while increased AST and CK concentrations were thought to be linked to muscle tissue damage. Gavazza et al. (4) and Sarma et al. (10) observed elevation of ALP in H. canis infection. Elevation of ALP seen in this report might be due to progression of schizogony within bone-morrow and hepatocytes, in addition to the spleen.

Kose et al. (11) recorded leucocytosis, haemoconcentration and microcytic hypochromic anaemia in haematological examination of disseminated metastatic TVT. In this report, the complete blood count revealed normocytic and hypochromic anaemia with neutrophillia as observed by Paramjit et al. (12) in a case of hepatozoonosis in a mongrel dog. Ruiz et al. (13) have previously recorded $H$. canis associated with canine TVT in Argentina. H. canis infection affects spleen, lymph nodes and bone marrow. Clinical signs vary from

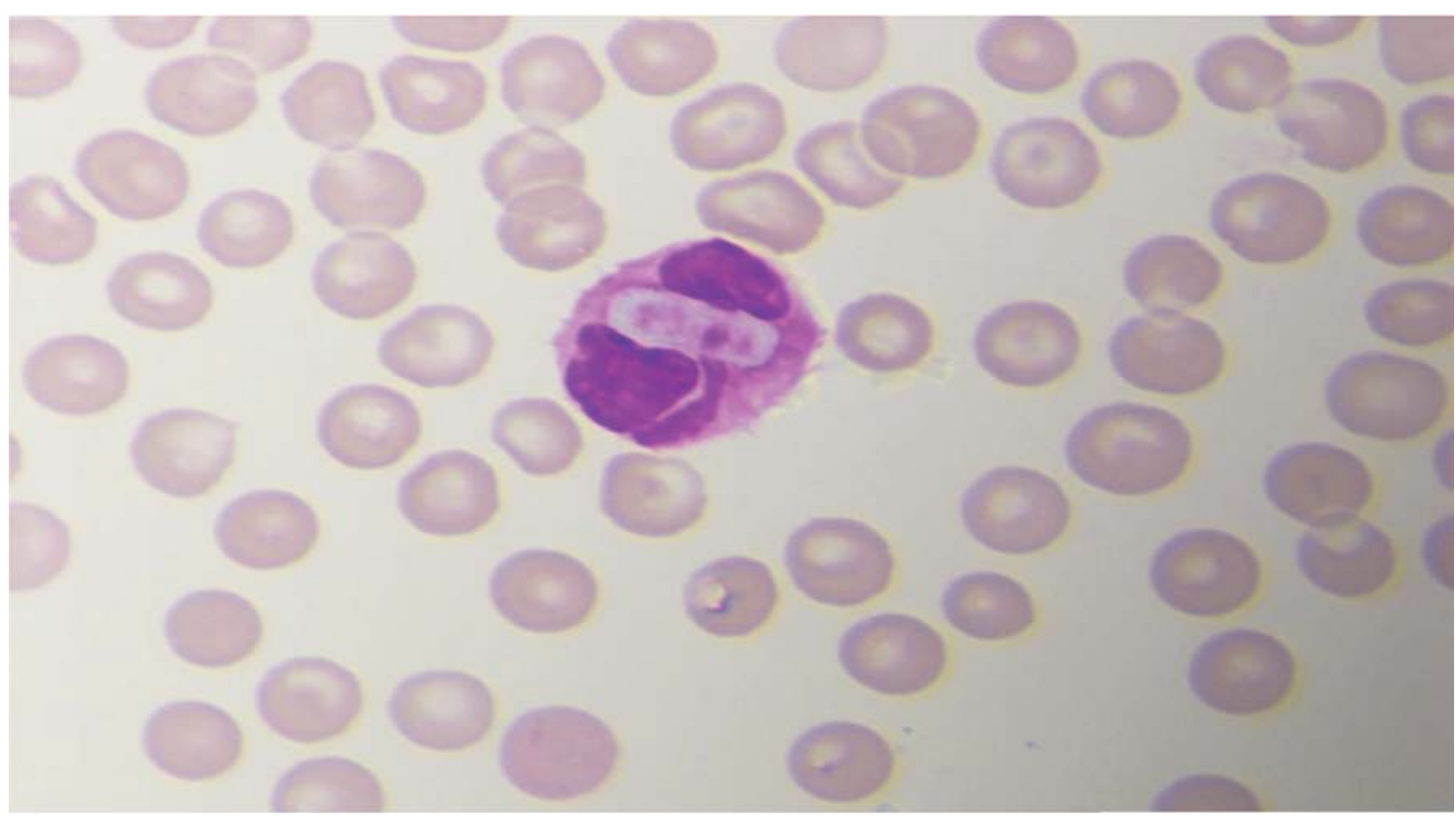

Figure 2. Peripheral blood smear from TVT affected dog showing ellipsoidal shaped H.canis gamonts in a neutrophil.

\section{DISCUSSION}

The TVT in dogs are transmitted not only by coitus, but also by licking, sniffing, biting, and scrabbling of the tumour affected area or through asymptomatic, mild or severe, including anaemia and lethargy, depending on the level of parasitemia and the immune status of the subject $(4,14)$. Hepatozoonosis is often found in association with other infections including blood parasites (15). 
The blood picture revealed rouleaux formation of RBCs, hypochromasia, leptocytes, neutrophilia. Rouleaux are stacks of RBCs which form because of the unique discoid shape of the cells. It occurs in inflammatory conditions, connective tissue disorders and in tumours due to the interaction of fibrinogen with sialic acid on the surface of RBCs. This is not an uncommon feature in an anaemic condition. Marino et al. (16) reported that sporadic Leishmania amastigotes were found within the canine TVT in three cases, probably transported by infected macrophages often infiltrating the tumour. Moreover, the capacity of tumour cells to internalize amastigotes suggests phagocytic and/or receptormediated endocytosis that could be related to the proposed histiocytic phenotype of TVT. A similar pattern of immune-reaction was observed in the present case. In addition to cytological examination of smears for the identification of tumour, the blood smears can necessarily be screened for the presence of parasites like $H$. canis as well.

Chemotherapy has been shown to be the most effective and practical therapy, with vincristine sulfate being the most frequently used drug. Vincristine can be intravenously administered at weekly intervals at a dose of 0.5 to $0.7 \mathrm{mg} / \mathrm{m} 2$ of body surface area or $0.025 \mathrm{mg} / \mathrm{kg}$, ranitidine at a dose of $0.2 \mathrm{mg} / \mathrm{kg} \mathrm{BW}$, and amoxicillin at a dose of $11 \mathrm{mg} / \mathrm{kg} \mathrm{BW}$ for 5 days (17). In this case, the animal was administered with vincristine sulphate injection at a dose of $0.025 \mathrm{mg} / \mathrm{kg} \mathrm{BW}$ at weekly intervals and ranitidine injection at a dose of $0.2 \mathrm{mg} / \mathrm{kg}$ BW. Oxytetracycline $(10 \mathrm{mg} / \mathrm{kg} \mathrm{BW}$ for 5 days $)$ followed by oral doxycyline $(10 \mathrm{mg} / \mathrm{kg} /$ day for 21 days) were also administered. Marked reduction in the size of tumors after 5 cycles of treatment was observed and blood smear examination revealed absence of $H$. canis schizonts.

\section{REFERENCES}

1. Goldschmidt, M. H., Hendrick, M. J. (2002). Tumours of the skin and soft tissues. In: Meuton, D. J. (Ed.), 4th ed., Tumours in Domestic Animals. (pp. 45-118). Press, Iowa. Iowa State.

2. Chu, R.M., Sun, T.J., Yang, H.Y., Wang, D.G., Liao, K.W., Chuang, T.F., Lin, C.H., Lee, W.C. (2001). Heat shock proteins in canine transmissible venereal tumor. Vet. Immunol Immunopathol. 82, 9-21. http://dx.doi.org/10.1016/S0165-2427(01)00327-0

3. Cohen D. (1985). The canine transmissible venereal tumor: A unique result of tumour progression. Adv Cancer Res. 43, 75-112. http://dx.doi.org/10.1016/s0065-230x(08)60943-4
4. Gavazza, A., Bizzeti, M., Papini, R. (2003). Observations on dogs found naturally infected with Hepatozoon canis in Italy. Rev. Méd. Vét. 154, 565-571.

5. Baneth, G., Samish,M., Shkap, V., (2007). Life cycle of Hepatozoon canis (apicomplexa: adeleorina: hepatozoidae) in the tick Rhipicephalus sanguineus and domestic dog (Canis familiaris). J. Parasitol. 93 (2): 283-299.

http://dx.doi.org/10.1645/GE-494R.1

PMid:17539411

6. Stettner, N., Brenner, O., Eilam, R., Harmelin, A. (2005). Pegylated liposomal doxorubicin as a chemotherapeutic agent for treatment of canine transmissible venereal tumor in murine models. J. Vet. Med. 67, 1133-1139.

http://dx.doi.org/10.1292/jvms.67.1133

7. Stockmann, D., Ferrari, H.F., Andrade, A.L., Lopes, R.A., Cardoso, T.C., Luvizotto, M.C.R. (2011). Canine transmissible venereal tumors: Aspects related to programmed cell death. Braz J. Vet. Pathol. 4, 67-75.

8. Oruc, E., Saglam, Y.S., Cengiz, M., Polat, B. (2011). Cytological diagnosis of breast metastasis of transmissible venereal tumor by fine needle aspiration and the treatment with vincristine sulphate in a dog. Ankara Üniv Vet Fak Derg. 6, 63-69.

9. Kerr, M.G. (2002). Clinical biochemistry and haematology. In: (2nd Ed.), Veterinary Laboratory Medicine (pp.135-147). Blackwell Science Ltd, USA.

10. Sarma, K., Mondal, D.B., Saravanan, M., Kumar, M., Mahendran, K. ( 2012). Haemato-biochemical changes in Hepatozoon canis infected dog before and after therapeutic management J. Vet. Parasitol. 26 (1): 35-38.

11. Kose, A.M, Cizmeci, S.U, Aydin, I, Dinc, D.A, Maden, M., Kanat, O. (2013). Disseminated metastatic transmissible venereal tumour in a bitch Eurasian J .Vet. Sci. 29, 1, 053-057.

12. Paramjit K., Deshmukh, S., Rajsukhbir, S., Bansal, B.K., Randhawa, C.S., Singla, L.D. (2012). Para-clinico-pathological observations of insidious incidence of canine hepatozoonosis from a mongrel dog: a case report. J .Parasit. Dis. 36(1): 135-138. http://dx.doi.org/10.1007/s12639-011-0092-x PMid:23543040 PMCid:PMC3284626

13. Ruiz, M.F., Zimmermann, R.N., Aguirre, F.O., Forti, M.S. (2013). Hepatozoon canis asociado a un tumor venéreo transmisible: singular hallazgo. Vet. Arg. 30, 306.

14. Baneth, G., Weigler, B. (1997). Retrospective casecontrol study of hepatozoonosis in dogs in Israel. J. Vet. Intern. Med. 11, 365-370. http://dx.doi.org/10.1111/j.1939-1676.1997.tb00482.x PMid:9470163 
Hepatozoon canis infection in a dog with TVT- Case report

15. Gondim, L. F. P., Kohayagawa, A., Alencar, N. X., Biondo, A. W., Takahira, R. F., Franco, S. R. V. (1998). Canine hepatozoonosis in Brazil: description of eight naturally occurring cases. Vet. Parasitol. 74, 319-323.

http://dx.doi.org/10.1016/S0304-4017(96)01120-X

16. Marino, G., Gaglio, G., Zanghi, A. (2012). Clinicopathological study of canine transmissible venereal tumour in leishmaniotic dogs. J. Small Anim. Pract. 53, 323-327.

http://dx.doi.org/10.1111/j.1748-5827.2012.01201.x PMid:22489831
17. Raghunath, M., Sudha Rani Chowdhary, Ch., Vidya Sagar, P., Ravi Kumar, P. (2015). Genital and extra genital TVT in a bitch- a case report. Sch J Agric Vet Sci. 2(1B): 61-62. 